\title{
Bilateral Agreement of Indonesia - Japan for Low Carbon Growth Cooperation: An Analysis of the Effectiveness and the Compliance Level
}

\author{
Hidayat Chusnul Chotimah ${ }^{1}$, Puguh Toko Arisanto ${ }^{2}$, Tiffany Setyo Pratiwi ${ }^{3}$ \\ ${ }^{1}$ Program Studi Ilmu Hubungan Internasional, Universitas Teknologi Yogyakarta - Indonesia \\ 2Program Studi Ilmu Hubungan Internasional, Universitas Teknologi Yogyakarta - Indonesia \\ ${ }^{3}$ Program Studi Ilmu Hubungan Internasional, Universitas Teknologi Yogyakarta - Indonesia
}

Email: hidayat.chotimah@staff.uty.ac.id Submitted: 20 July 2020 | Accepted: 18 December 2020

\begin{abstract}
To reduce greenhouse gas emissions, in 2013 Indonesia and Japan agreed to establish bilateral cooperation in Joint Crediting Mechanism (JCM). JCM facilitated and encouraged Japanese institutions (private and state) to cooperate with Indonesian institutions in a form of investment in low-carbon development. This article seeks to analyze the effectiveness of JCM implementation between Indonesia and Japan by using international cooperation effectiveness approach to determine the legal form whether soft law or hard law. The results show that both Indonesia and Japan choose to use soft law in this negotiation which has several benefits. Soft law provides an opportunity for both countries to achieve their goals and it can be used as a tool for negotiation and compromise. This article will also analyze the level of compliance between the two countries through coercion, reciprocity, reputation, and domestic institutions approaches. Authors found that there is no coercion in the form of sanction in implementing JCM; there is a reciprocity allowing JCM to provide financial assistance, transfer of technology and human resource; Indonesia and Japan keep their promises to uphold their international commitments; and domestic institutions play a role in promoting compliance in the low carbon growth partnership between the two countries.
\end{abstract}

Keywords: Cooperation, Partnership, Bilateral, Low Carbon, Japan, Indonesia

\begin{abstract}
Abstrak
Untuk mengurangi emisi gas rumah kaca, pada tahun 2013 Indonesia dan Jepang sepakat menjalin kerjasama bilateral dalam Joint Crediting Mechanism (JCM). JCM memfasilitasi dan mendorong institusi Jepang (swasta dan negara) untuk bekerjasama dengan institusi Indonesia dalam bentuk investasi dalam kegiatan pembangunan rendah karbon. Artikel ini berupaya menganalisis efektifitas implementasi JCM antara Indonesia dan Jepang dengan menggunakan pendekatan efektivitas kerjasama internasional untuk menentukan bentuk hukum apakah soft law atau hard law. Hasil penelitian menunjukkan bahwa Indonesia dan Jepang memilih menggunakan soft law dalam negosiasi ini dengan beberapa keunggulan. Soft Law memberikan kesempatan bagi kedua negara untuk mencapai tujuan mereka dan dapat digunakan sebagai alat untuk negosiasi dan kompromi. Lebih lanjut, artikel ini juga akan menganalisis tingkat kepatuhan kedua negara dalam perjanjian JCM melalui pendekatan koersi, timbal balik, reputasi, dan institusi domestik. Penulis menemukan bahwa tidak ada paksaan berupa sanksi dalam menerapkan JCM; adanya timbal balik yang memungkinkan JCM memberikan bantuan keuangan, transfer teknologi maupun sumber daya manusia; Indonesia dan Jepang menepati janji untuk menegakkan komitmen internasional mereka; dan institusi domestik berperan dalam mempromosikan kepatuhan pada kemitraan pertumbuhan rendah karbon diantara ke dua negara tersebut.
\end{abstract}

Kata Kunci: Kerjasama, Kemitraan, Bilateral, Rendah Karbon, Jepang, Indonesia. 


\section{INTRODUCTION}

For some years, Japan has been hailed as a quite intense state addressing environmental issues, particularly carbon gas emissions. Recorded since 2008, Japan had embarked on its actions in search of cooperation with developing countries that have environmental awareness in climate change issues. For examples, Prime Minister, Yasuo Fukuda actively initiated "Cool Earth Partnership" to support developing countries; then in 2009, Yukio Hatoyama, the next Prime Minister of Japan, launched the "Hatoyama Initiative" program, a program that targeted carbon emissions reduction up to $25 \%$ by 2020 by providing financial assistance up to $\$ 15$ billion to work with developing countries (Toyota and Fujikura, 2012, p. 181). In a line with Japan, Indonesia, a developing country, has the same awareness to reduce carbon emissions because the carbon intensity residing in this country is still very high. Data derived from the International Energy Agency showed, the contribution of gas and coal combustion increased from 14 to 21 percent and from 1 to 26 percent in the mid-2000s. In 2009, President Susilo Bambang Yudhoyono at the G20 meeting conclusively affirmed a national program to reduce carbon emissions by 26 percent by 2020 and even if with international assistances,
Indonesia can potentially reduce gas emissions by $41 \%$ (Mori, Ekins and Speck, 2013, p. 252). This fact shows both Japan and Indonesia are equally addressing the issue of growth of carbon gas emissions.

It was newly in 2013, the similar vision of the two countries was implemented in the form of bilateral cooperation under the Joint Crediting Mechanism or abbreviated as JCM. The establishment of a bilateral agreement between Japan and Indonesia on JCM aims to intertwine a cordial partnership in achieving lowcarbon development. This cooperation constitutes a type of important strategies to protect the environment by reducing gas emissions. By providing fund and transfer of sophisticated and advanced technology tools for low-carbon development in Indonesia, Japan will reap a carbon quota of low-carbon development outcomes from Indonesia, whereas Indonesia will also benefit from the low-carbon development for lower costs and technology transfer of the program due to Japan assistances.

Some literatures described the bilateral cooperation between Indonesia and Japan under JCM such as Husni (2017). His article explained JCM as the form of inter-city cooperation or green sister city 
between Surabaya city (Indonesia) and Kitakyushu city (Japan). Meanwhile, Chotimah \& Winanti (2018) viewed this cooperation from domestic politics of Japan perspectives. Then, other scholars like Hasanah \& Puspitasari (2019) identified from neoliberalism approach with the concept of international cooperation in the field of environment.

Most of the previous studies looked at the aspects of how cooperation between Indonesia and Japan under JCM was carried out. In fact, it is very important to assess the agreement that has been implemented whether effective or not. In this context, we identify this as research gap because the previous literatures have yet to analyze it.

The effectiveness of international agreement is a crucial matter to assess costs and benefits of the agreement. By assessing the effectiveness of the agreement, we will find out the form of legalization or a rule of the agreement whether it is soft law or hard law. These two forms of legalization refer to "weak or strong" or "hard or soft" binding rules on the parties involved. The author will analyze this study through the framework of effectiveness of international cooperation and in so doing will explain the level of compliance between the two parties in the JCM agreement through coercion, reciprocity, reputation, and domestic institutions approach.

\section{METHOD}

This study uses qualitative and descriptive methods to find the answers in a particular social setting (Lune \& Berg, 2017). The social setting refers to bilateral agreement between Indonesia and Japan in Low Carbon Growth Cooperation under JCM and also the effectivenees and the compliance of this agreement. The data were collected through existing statistics and previous studies, which are relevant to the research topics.

\section{THEORETICAL FRAMEWORK}

\section{Assessing Effectiveness of International Agreement}

Zovko (2005, p. 111) saw the effectiveness of the international regime as a concept can be seen from two elements of evaluation, namely the impact of the international regime on the addressed problems; and using a regime's authority as a measure of effectiveness through successful enforcement and compliance.

Meanwhile, according to Goldstein et al. (2000, p. 387) the legalization of an agreement (or treaty) is one of the most vital parts to assess the effectiveness of legal products produced by an international organization. The effectiveness or 
ineffectiveness of the implementation of agreement rule in international law is largely determined by the form of legalization or the international rules whether it is soft law or hard law. These two forms of legalization refer to "weak or strong" binding rules on the parties involved.

Pronto (2015) stated that a rule can be "hard" though it is not enclosed in "hard" form or it has elements of "hard" and "soft" law in practice which simultaneously refer to its form and substance. In other words, it refers to an instrument that is adopted (or not) in one of the accepted "hard" or "soft" legal forms. As well as whether it is "binding" or not.

The definition of hard law often refers to legally binding provisions that deal with rights and obligations imposed on the involved parties. Meanwhile, the definition of soft law can be interpreted as the opposite of hard law as it refers to "principles, norms, standards or other statements of expected behavior" and there is no element of rights and obligations of actors to comply with these rules. (Choudhury, 2018, p. 3 ).

Furthermore, in the concept of legalization, Abbot et al. (2000, p. 401) provided three measures to assess if the agreement in the form of hard law or soft law, namely obligation, precision and delegation. Obligation can be depicted that a state is bound to meet obligations or commitments mentioned in an agreement. Thus, the behavior of the state is limited by a set of rules or commitments that have been compiled and agreed upon or they are under the general rules, procedures and discourse of international law. (Abbot, et al., 2000, p. 410). Precision means that rules unambiguously define the conduct they require, authorize, or proscribe. While the delegation, according to Abbot, et al means certain third parties granted an authority implement, interpret and apply the rules, resolve disputes and (possibly) make further rules.

Meanwhile, an international agreement will be effective if there is a mechanism in its enforcement to impose compliance of the parties involved in the agreement. Compliance in the international context refers to the behavior of actors in accordance with the explicit rules of the agreement. Measuring the level of compliance of actors to commit to international agreements conceptually ensures why compliance or noncompliance occurs. (Raustiala, 2000, p. 391).

In this case, according to Jana von Stein (2010), there are several ways for a state to comply with an approved agreement namely coercion, reciprocity, reputation, and domestic 
institutions. According to Stein (2010), coercion can be negative or positive. It can entail punishments such as trade sanctions, decreases in development assistance, or even military intervention; but, alternatively, it can consist of rewards like increased aid or conclusion of an international agreement.

Then, reciprocity is an equivalent value exchange in which actions of each party depend on actions of others such as goodness rewarded with goodness, and badness rewarded with evil. Meanwhile, Stein (2010) mentions a reputation as the reason of state for keeping promises. It can ease governments to secure cooperation in the future and in other issue-areas. In contrast, a reputation for unreliability may well hinder cooperation because promises to abide might appear noncredible. The last, in domestic institution, Stein (2010) focuses on the domestic constraints as sources of domestic law enforcement towards international law (Stein, 2010).

Furthermore, several variables or factors can define an international agreement as a regime of behavioral determinants at the international level. Those are transparency, robustness, transformation rules, government capacity, power distribution, interdependence, and intellectual actor (Young, 1992).

\section{FINDINGS AND DISCUSSION}

The bilateral cooperation agreement between Indonesia and Japan on the JCM for the Low Carbon Growth Partnership was signed by Japan Foreign Minister, Fumio Kishida in Tokyo on August 7, 2013 and Coordinator Minister for Economic Affairs of the Republic of Indonesia, M. Hatta Rajasa in Jakarta on 26 August 2013.

Based on the contents of the $\mathrm{MoU}$ in the implementation of JCM under a low-carbon growth partnership between Japan and Indonesia, it can be systematically analyzed the degree of obligation, precision and delegation.

\section{Degrees of Obligation}

Degree of obligation can be analyzed from $\mathrm{MoU}$ in the implementation of JCM that has 14 sections. In the section 1 about the purpose of establishing a low-carbon growth partnership, in which the existing obligation is moderate because there exists a word "promote" which literally does not contain obligations to engage in partnerships. It is more emphasized only on the effort to encourage partnerships. Meanwhile in the sections from 2 to $6,8,9$ and 12 of the $\mathrm{MoU}$ have a high obligation due to the clear rules of directions and the words used are assertive. Then other sections are moderate. 


\section{Degrees of Precision}

In analyzing the degree of precision, there are five sections which are moderate degree, namely section 2 , 4, 5, 8 and 12 from 14 sections of $\mathrm{MoU}$ and the others are high degree of precision because there are explicit statements binding the actors to comply it.

\section{Delegation}

There is no rule referring to delegated third parties in assisting the implementation of a low-carbon growth partnership between Japan and Indonesia. Yet to carry out the JCM and to verify the approved projects, both parties require third parties as facilitators. For example, in the project of Energy Saving for Air-Conditioning and Process Cooling by Introducing High-efficiency Centrifugal Chiller in Batang, Central Java involved participants from Japan, namely Nippon Koei Co., Ltd. (Focal Point), Ebara Refrigeration Equipment \& Systems Co., Ltd. Meanwhile, participant of Indonesia as host country is PT. Primatexco Indonesia. They involve third party entity namely Lloyd's Register Quality Assurance Limited (LRQA) for validating the project (Rocamora, et. al., 2016).

Based on the analysis (obligation and precision) of the MoU on Low Carbon Growth Partnership between
Japan-Indonesia, it can be seen that the partnership established has a moderate degree of legalization both obligation and precision; and no delegation. Thus, we can infer that the legalization applies soft legalization. The soft legalization implies a soft law form. Lately, Japan and Indonesia choose the soft law form, if we examine further, because soft law is considered more profitable in international cooperation; hard law facilitates international interactions in many discussions, but has high costs and limitations (rigid).

\section{Advantages of Soft Legalization}

The advantages of soft legalization as revealed by Abbott and Snidal (2000, pp. 434-444) are as follows:

\section{Contracting Costs}

The consequences of soft law require less contracting costs than hard law, so it becomes more attractive and tends to be chosen by countries in drafting an agreement. (Demedts, 2018, p. 55). A country can generally avoid from binding lawsuits and high costs as the aftermath of the cooperation.

This can be seen from Japan's interests that in the aftermath of the Fukushima nuclear disaster in 2011, Japan had suffered enormous economic losses. To undertake a commitment to mitigate climate 
change in greenhouse gas emission through renewable energy projects in domestic level, Japan very likely spends so a large cost (Sofer, 2016) that with this $\mathrm{MoU}$, Japan can execute its international commitments in Indonesia territory which is much more profitable.

While for Indonesia, this cooperation does not spend a large cost. Because it was mentioned on $\mathrm{MoU}$ that the financial, technological and capacity building supports emanate from both parties and therefore the costs imposed on the implementation of JCM can be minimized by Indonesia. Thus, Japan and Indonesia choose this soft law recorded in the MoU as the cornerstone for a low-carbon growth partnership because of its low binding and cheaper costs (Sofer, 2016).

\section{Sovereignty Costs}

Demendts (2018) stated that soveregnity costs refers to the limitation imposed on the sovereign will of the state following the agreement. In this case, states may derive benefits from cooperation only when the perceived benefits outweigh the perceived costs from the cooperation.

Japan and Indonesia preferred to choose the form of $\mathrm{MoU}$ because of sovereignty or authority consideration.
Both parties do not accept their sovereignty to be limited by third parties for fear that dispute occurs in the future or during its implementation of agreement. Therefore, Japan and Indonesia favored to form a Joint Committee whose memberships come from Ministries or State agencies of both countries. In addition, if they involve third parties in this $\mathrm{MoU}$, they can possibly get certain sanctions in case a dispute occurs. In other words, both parties sought to apply safe mode in their agreement.

\section{Uncertainty}

Uncertainties in international cooperation relations on new issues bring about difficulties for countries to anticipate the issues due to their limits to cope with the problems. One of issues in the scope of climate change is environmental issue that brings many uncertainties which then can effect on the economy for both Japan and Indonesia. A MoU provides an opportunity for both countries to delve into the impacts of agreed rules and achieves the desired goals and benefits in accordance with their international commitments under the UN Climate Change rules in article 2 of the UN Climate Change Convention. At the same time, both countries can avoid in consequence adverse possibilities which suddenly arise from the applied rules. 


\section{Tool of Compromise}

$\mathrm{MoU}$ as a cooperation agreement that has soft legality can be used as a tool for negotiation and compromise. A MoU facilitates countries conducting cooperation to adjust their commitments. Japan-Indonesia MoU in which the two parties negotiate and compromise their goals and interests of both countries can be accommodated. This can be seen in the sections or provisions $10,11,13$ \& 14 of the MoU. Provision 10 states that both parties work closely in facilitating financial, technological and capacity building support necessary for JCM implementation. Herein, the stakeholders that provide the supports can be compromised and negotiated.

Provision 11 mentions a consultation for the transition to the mechanism of the type of tradable carbon credits and consultations related to the transition time is also negotiable. Furthermore, provision 13 about the development of negotiations under the convention and provision 14 about content amendment enable both parties to negotiate and compromise on how to amend or modify the contents of the MoU.

\section{Compliance Level in the} Implementation of the Joint Credit Mechanism

International law enforcement is different from domestic law.
Therefore, the level of compliance in JCM implementation for low-carbon growth partnership between Japan and Indonesia can be viewed from coercion, reciprocity, reputation, and domestic institutions of each country as mentioned by Stein (2010).

\section{Coercion}

Coercion in this study can be seen in the context of financial support for Japanese and Indonesia enterprises provided by Ministry of Economy, Trade and Industry (METI) of Japan and Ministry of Environment (MOE) of Japan. There are either economic sanctions or military sanctions for implementing bilateral agreement under low carbon growth partnership between Japan and Indonesia, because that agreement mutually benefit for both parties. Financial support will be provided for enterprises which eligible by conducting feasibility studies on the registered projects (DNPI, 2013, p. 75). Therefore, in the context of low carbon growth partnership between Japan and Indonesia is no coercion.

\section{Reciprocity}

Reciprocity is conceived as an essential engine for compliance with international law. Keohane (1984, p. 8 in von Stein, 2010) defined reciprocity as an equivalent value exchange which actions of each party depend on actions of others such as goodness 
rewarded with goodness, and badness rewarded with evil. In the implementation of the low-carbon growth partnership between Japan and Indonesia through the JCM mechanism, reciprocity occurs which JCM allows for financial assistance, technological transfer as well as human resources as mentioned in the MoU's agreement on JCM. In addition, this mechanism will be an incentive for Japanese companies to increase investment in low-carbon activities in Indonesia. Japanese government benefits as a portion of the greenhouse gas emission reduction result in investment projects in Indonesia will be claimed as the country's emissions reductions. Indonesia also enjoys great benefits, both economic and environmental benefits, from the JCM cooperation (DNPI, 2013).

\section{Reputation}

Reputation can have real material consequences. Reputation to keep promises, for example, can make it easier for governments to secure future cooperation. Japan will most probably enforce the rules of the low carbon growth partnership agreement through JCM because Japan has been known as a developed country upholding cultural values, honesty and discipline (Fox, 2009). Meanwhile, Indonesia will also implement the rules of the MoU considering that Japan is Indonesia's main partner in various international cooperations and as old friend or old brother.

\section{Domestic Institutions}

Some international law scholars stressed the importance of domestic institutions in promoting compliance. In common, there are two sources of domestic enforcement: election and court. If a country makes international legal commitments and then violates, its citizens may want to punish its leaders because it is more easily attainable in democracy system, such as elections that provide easily reachable means of punishing leaders (i.e. expelling them from their offices). Fears of such punishment can deter democratic leaders from violating international agreement. Japan and Indonesia implement democratic system. Fortunately, Japanese people have deep insight of environmental issues which encourages awareness to preserve environment. Moreover, some decades ago, Japan encountered domestic constraint of pressure group from environment activist to preserve it (Fox, 2009). This stereotype will most possibly encourage Japan to comply with the MoU. Whereas, Indonesia has interest groups of environmental NGOs that will readily protest Indonesia's actions when it does not comply with international rules on climate change given that Indonesia is the third biggest contributor of greenhouse gas emissions (Pasaribu, 2012). 
Meanwhile some determinative variables of international agreement as a regime of behavioral determinants at international level are transparency, robustness, transformation rules, government capacity, power distribution, interdependence, and intellectual actor as stated by Oran Young.

\section{Transparency}

Transparency is a behavioral regulatory function which monitor compliance with rules, especially presumptions of non-compliance with agreed rules ensue (Young, 1992: 177178). Both Japan and Indonesia in the MoU have strong transparency values which can be blatantly seen from provisions $6,7,8$, to 9 . In terms of provision 6 , it is stated that both parties are all together stipulating JCM implementation rules and guidelines; both parties openly know about the rules and guidelines. Provision 7 mentions both Japan and Indonesia recognize that the reduction quota from mitigation projects can be used as a part of the greenhouse gas mitigation efforts in accordance with the international commitments of each country. This recognition confirms the MoU signed must be abided by both parties without any manipulation. Provision 8 mentions that the implementation of a strong and transparent methodology with good integrity intends to encourage concrete actions to reduce greenhouse gas emissions. This reflects the real form of bilateral relations ensuring the parties involved to have full responsibility. In Provision 9, both parties ensure that double counting does not occur in the reduction or removal of greenhouse gas emissions. This confirms efforts of both parties to monitor every progress of the JCM program in detail in accordance with the applied procedures.

\section{Robustness}

Robustness has two distinct dimensions, strong and fragile tenacity. The resilience of the social choice mechanism addresses regime's capacity to adapt to changes or disturbances that occur in the wider social environment without radical transformation (Young, 1992: 179).

Japan and Indonesia implement a strong institutional system. It lies in provision 10 of the MoU which points out clearly that both parties facilitate each other through financial, technology and capacity building supports necessary for JCM implementation. Article 2 of the UNFCCC as the objective of JCM program implementation becomes a milestone of cooperation relation between the two countries that is not easily vulnerable. Not to mention, two parties conduct close policy 
consultation at various levels as mentioned in provision 2 .

\section{Transformation Rules}

Rules in the $\mathrm{MoU}$ agreed by Japan and Indonesia are dynamic, meaning it is very possible if there is an amendment or change of rules in accordance with the terms and agreement of both parties. Moreover, this is supported by form of soft legalization both parties apply with the result that it allows for changes in the rules if required in the future in a line with provisions $13 \& 14$ in the $\mathrm{MoU}$.

\section{Government Capacity}

The effectiveness of international institutions is highly dependent on the extent to which the state can implement the established rules of the community within its jurisdiction and comply consistently with the rules (Young, 1992: 184). Japan's consistency and commitment to carbon-emission reduction efforts are unquestionable, seeing that the awareness and support of its people as well as large budgets that Japan has spent on programs to reduce the growth of carbon-gas emissions are high. This is based on Article 29 about Bill for the Basic Act on Global Warming Countermeasures, describing that Japan will create a mechanism for properly valuing contributions to GHG emission reduction efforts overseas.
Meanwhile, Indonesia's consistency and commitment to carbon emissions reduction efforts are not as high as Japan, seeing that its people's awareness is still low to preserve environment and to reduce the use of goods or vehicles that contribute to carbon emissions. However, Indonesia's commitment should be appreciated, since the government of Indonesia had ratified the Kyoto Protocol through law No. $17 / 2004$ on the UNFCCC bringing the consequences that Indonesia is directly or indirectly involved in addressing climate change issues.

\section{Power Distribution}

Power distribution usually brings about two classes that dominate the social structure. Subjects who have weak positions must carry out rules, decisions, or suggestions of frequently suppressive international institutions (Young, 1992, pp. 185-186). Japan has greater power in terms of financial, technological, and human resources compared to Indonesia if we examine carefully the power structure in JCM cooperation. It is not surprising if there is a possibility that Japan dominates in the implementation of the cooperation. In addition, Japan has a very larger number of third parties than those of Indonesia. However, if we refer to provision 4 of the $\mathrm{MoU}$, it states that both parties create a Joint 
Committee to operate JCM, which consists of representatives from both parties. This indicates that the Joint Committee can be used as a forum for making balanced institutional agreements which more emphasize concrete steps of the JCM rather than focus on identifying the strong and the weak.

\section{Interdependence}

The interdependent states will be more vulnerable and tending to be reactive for behaviors of other states. The higher level of interdependency that they create, the greater impact that they receive. The perspective for understanding the principle of interdependence can be reviewed through decision-making interaction. The interaction of decision-making involves a situation which two or more actors are interrelated and influence the outcome of each actor. The greater effect that may arise, the higher level of dependence is (Young, 1992, p. 188). JCM's MoU rules are firm and clear, one of which is to ensure the JCM implementation methodology. Both Japan and Indonesia are interdependent on succeeding carbon emission reduction. Both countries are open to negotiate on what will be carried out. Thus, the interests of both countries can be accommodated without problematizing who is more dependent. However, the important thing to embed in mind is the status that Indonesia is a developing country and Japan as a developed country with much better the availability of technology cannot be just denied. Therefore, negotiation and compromise become significant ways to unify the interests of both countries.

\section{The Role of Intellectual Actors}

It took long process that ideas on environmental conservation transformed and were accepted by the international communities to be current international regimes. This also prevailed when a new JapanIndonesia bilateral cooperation were implemented in 2013 whereas climate change has occurred much earlier. However, if we look back in the past, communities and NGOs focusing on environmental issues have been founded in Indonesia since the 1980s. For example, the Indonesian Forum for the Environment (WALHI), which has been actively campaigning on environmental issues and reaping assistances from foreign communities and institutions. It is no doubt if Indonesian government will get supports from environmental activists to implement JCM.

\section{CONCLUSION}

The aforementioned discussion and analysis on the effectiveness of 
bilateral agreement on JCM for the low carbon growth partnership between Japan and Indonesia can be summarized several important points, i.e. (1) Japan-Indonesia established a partnership that has a moderate degree of legalization that is moderate obligation and precision with no delegation referring to soft legalization. A soft legalization expresses a form of soft law resulting in not binding, not rigid rules; (2) Japan and Indonesia choose soft law due to two aspects; avoid from binding lawsuits and high costs; (3) JCM between Japan and Indonesia brings about high level of compliance which can be seen from coercion, reciprocity, reputation, and domestic institutions; (4) the level of transparency of the cooperation is high referring to the contents of $\mathrm{MoU}$ emphasizing transparency and integrity in JCM's methodology implementation; consistency and commitment of both countries are relatively same though it cannot be denied that Indonesia's consistency and commitment are still lower than those of Japan; (6) Japan has greater power than Indonesia but negotiation and compromise can be effective ways to unify the interests of both countries in implementing the JCM.

An analysis of the effectiveness and the compliance level of bilateral agreement of Indonesia and Japan in
Low Carbon Growth Partnership can bring new insights for field of International Relations study. For one reason, this research does not only look perspectives of the costs and benefits of the two countries but also provides knowledge about how to assess or review the contents of the agreements that have been made and agreed upon by the two countries.

This research still has some shortcomings. Thus, the coming research can complement the existing shortcomings in this research. In this case, the next research can focus on discussing the aspects of cooperation between Indonesia and Japan under the JCM by bridging aspects of business profits and human rights.

\section{REFERENCES}

Abbott, Kenneth W., et. al (2000) The Concept of Legalization. The IO Foundation and the Massachusetts Institute of Technology.

Abbott, Kenneth W. \& Snidal, Duncan. (2000) Hard and Soft Law in International Governance. International Organization, Vol. 54, No. 3.

Chotimah, H. C., \& Winanti, P. S. (2018) The Politics of Green Capitalism: Formulating the Low Carbon Growth Partnership between Japan and Indonesia. KnE Social Sciences, 3(5), pp. 291-311.

Choudhury, B. (2018) Balancing Soft and Hard Law for Business and Human Rights. International and Comparative Law Quarterly, 67(4), pp. 961-986. 
Demedts, V. (2018) The Future of International Competition Law Enforcement: An Assessment of the EU's Cooperation Efforts. Boston: Brill.

Dewan Nasional Perubahan Iklim. (2013) Mari berdagang karbon: Pengantar pasar karbon untuk pengendalian perubahan iklim. [Carbon trading: introduction to carbon market for climate change control] [in Bahasa Indonesia]. Available at: http://jcm.ekon.go.id/en/uploads/fil es/Document $\% 20 J C M / M e d i a / b u k u$ carbon_isi.pdf. (Accessed: 27 December 2015).

Fox, Midori K. (2009) The Ethics of Japan's Global Environmental Policy, Dissertation. Doctor of Philosophy in Asian Studies, School of Social Sciences, University of Adelaide.

Goldstein, Judith, et. al. (2000) Introduction: Legalization and World Politics (eds.). Cambridge: MIT Press.

Hasanah, L., \& Puspitasari, V. (2019) Kerja Sama Indonesia-Jepang dalam Joint Credit Mechanism (JCM) pada Pembangunan Rendah Karbon di Indonesia. Padjadjaran Journal of International Relations, 1(2), pp. 142155.

Husni, Z. (2017) Kerjasama IndonesiaJepang Melalui Joint Crediting Mechanism dalam Green Sister City Surabaya-Kitakyushu. JOM FISIP, 4(2 Oktober), pp. 1-14.

Lune, H., \& Berg, B. L. (2017) Methods for the Social Sciences Global Edition (Global edi). Essex, England: Pearson Education Limited.

Memorandum of Understanding. (2013) Bilateral Cooperation on the Joint Crediting Mechanism for the Low Carbon Growth Partnership between the Republic of Indonesia and Japan (Online). Available at: http://treaty.kemlu.go.id/uploads-
pub/2634_JPN-2013-0497.pdf.

(Accessed: 27 December 2016).

Ministry of Economy, Trade, and Industry (METI) Japan. (2013) Japan and Indonesia signed a low carbon growth partnership for promoting the Joint Crediting Mechanism (Online). Available at: http://www.meti.go.jp/english/press /2013/0830_02.html. (Accessed: 16 August 2017).

Mori, Akihisa, Ekins, Paul and Speck, Stephan. (2013) The Green Fiscal Mechanism and Reform for Low Carbon Development: East Asia and Europe. London: Routledge.

Pasaribu, Rowland B.F. (2012) Perekonomian Hijau di Indonesia (Online). Available at: http://rowland_pasaribu.staff.gunada rma.ac.id/Downloads/files/35481/pe rekonomian-hijau-indonesia.pdf. (Accessed: 27 September 2016).

Pronto, A. (2015) Understanding the Hard/Soft Distinction in International Law. V anderbilt Journal of Transnational Law, 48(4), pp. 941-956.

Raustiala, K. (2000) Compliance \& Effectiveness in International Regulatory Cooperation. Case Western Reserve Journal of International Law, 32(2), pp. 387-440.

Rocamora, A., et. al. (2016) IGES Climate policy and market mechanism status report 2016. Institute for Global Environmental Strategies, Japan. Available at: https://pub.iges.or.jp/countryhandbook-english[NR1] (Accessed: 17 August 2016).

Sofer, Ken. (2016) Climate politics in Japan: The impacts of public opinion, bureaucratic rivalries, and interest groups on Japan's environmental agenda. Sasakawa US A, Forum Issue No.1. Available at: https://spfusa.org/sasakawa-usa- 
forum/climate-politics-japan/. (Accessed: 1 June 2016).

Stein, Jana von. (2010) "Interrnational Law: Understanding Compliance and Enforcement", dalam The International Studies Encyclopedia. Denemark, Robert A. Blackwell Publishing.

Toyota, Tomoyo and Fujikura, Ryo. (2012) Climate Change Mitigation and Development Cooperation. London: Routledge.
Young, Oran R. (1992) The Effectiveness of International Institutions: Hard cases and critical variables. In Rosenau, James N., dan Ernst-Otto Czempiel (ed.), Governance without government: Order and change in world politics.

Cambridge: Cambridge University Press.

Zovko, I. (2005) International Law-Making for the Environment: A Question of effectiveness. In University of Joensun (Vol. 1). 